\title{
Study on the Impact of Color Image and Safety Cognition on Consumers' Car Purchasing Behavior
}

\author{
Chin-Tsu Chen \\ Assistant Professor, Department of Commercial Design and Management, \\ National Taipei University of Business. Taiwan \\ Dr. Chun-Fu Chen \\ Associate Professor, Department of Commercial Design and Management, \\ National Taipei University of Business. Taiwan
}

\begin{abstract}
With the prevailing use of cars in daily life, more and more people start considering safety regarding the color of cars and accident rate. For the concern of safety, some people even attempt to treat the color of cars as a priority when buying cars. However, the color design of an automobile is more than just beauty and fashion, it is also an indicator of safe driving. This study aims to probe into the impact of the color image of cars, safety cognition, and consumers' car purchasing behavior when purchasing a car in Taiwan. This study collects data through questionnaire survey and the SPSS statistical analysis program, and conducts $t$ testing, one-way ANOVA, Pearson productmoment correlation analysis, and regression analysis to validate the hypotheses. According to analytical research results, car owners' color image positively and significantly influences safety cognition; car owners' color image positively and significantly influences consumers' car purchasing behavior; car owners' safety cognition positively and significantly influences consumers' car purchasing behavior.
\end{abstract}

Keywords: car owners, color image, safety cognition, consumer behavior

\section{INTRODUCTION}

Color exists in daily life, and is essential and influential in daily human situations. Color is originated from human eyes, which receive it and trigger the brain. The stimulus of color is depicted physically, and through personal experience, includes affection by stimulus signals, thus, colors have different significance to different people. Research related to color images in recent years is generally applied to the lives of human beings. Color image refers to people's feelings toward color; in other words, the general characteristics of color psychology result in special feelings. Many chromatics researchers have explored the reasons for people's color selections (Chan, 2008). Product design and visual feelings are associated with color, as color enhances aesthetics and is a significant factor to demonstrate car owners' unique style.

Since cars are prevalent in daily life, more and more people start considering the color of cars, and some even treat color as a priority when selecting a car. They realize that the color of a car is more than beauty and fashion, it is also an indicator of safe driving. Currently, there are few studies in Taiwan regarding car color and safety. However, in the color design of cars, how to include the concern of safety to design competitive products that satisfy consumers' needs is a new issue encountered by the current automobile manufacturing industry.

As cars become more important in people's lives, there are more people buying cars, and all drivers are concerned about safety. Some people think that cars painted in bright colors will 
have fewer accidents, since bright colors draw the attention of other drivers. In the early morning, evening, or on rainy days when the light is dim, there are usually more traffic accidents. Moreover, color and light are associated; in comparison to dim colors or colors with low light reflection, cars with bright colors might result in fewer accidents.

The car purchasing behavior is considered high engagement consumption, and requires many decisions, as they must consider brand, function, and price, as well as color. In recent years, studies have demonstrated the impact of car color on driving safety and the theft rate of cars. Professor Sue Furness studied the colors of more than 1000 cars, and demonstrated that the accident rate of silver cars is the lowest; those of white, yellow, grey, red, and blue cars are the same; while the accident rate of dark cars (black, brown, or green) are two times more than other cars (Travel Encyclopedia, 2015).

NRMA Insurance, the largest automobile insurance company in Australia, conducted similar research on the relationship between the colors of cars and accidents, and the results showed that, the accident rates of dark and black, gold, green, and blue cars (similar to the color of roads) are much higher than bright colored cars (light yellow, cream-colored, milk-colored, and white). According to the explanation of scientists, at the same distance, silver, white, and yellow cars appear closer and are visually larger, thus, the drivers behind will be cautious when following or overtaking such cars. In addition, Tilburg University in the Netherlands investigated the relationship between car color and the theft rate, and demonstrated that when the color of a car is more fashionable, the theft rate will be higher. Black, silver, gray, and blue cars are favored by thieves. The visual brightness of color is different for different people; red and yellow are bright colors and have better visual effects, while dark cars are visually smaller and obscure. However, as the focus of this study considers the safest color, this research aims to explore car consumers' color image and safety cognition, and probes into the differences of automobile consumers regarding color image, safety cognition, and car purchasing behavior. Through color image applications in daily lives, this research studies consumers' selections of color and safety cognition when purchasing cars in order to propose criteria regarding both color and safety cognition for the public.

\section{Color image}

\section{LITERATURE REVIEW}

Color image is psychological performance and feeling, and means human perception when seeing a color or the psychological feelings caused by the color. Color image is formed by human intuition, past experience, memory, and unconscious process. Some perceptions are common to all human beings, while some are different according to different nations, cultures, or regions. Lai (1997) explained that color image is the impression when seeing color and the mental feelings originated from the color. When selecting color, preference is the key factor; however, mental feeling according to color is the most important factor. Light colors look young and fresh; dark colors are legitimate and stable, thus, the "young and fresh" perception of light color and the "legitimate and stable" perception of dark color are the images of color. In the human sensory system, a large number of color messages are received through vision, and are possible factors to trigger people's emotional reactions. The Japanese chromatics researcher, Junichi (1996), proposed the percentages of external stimulus received by sensory organs: vision $(87 \%)$, hearing $(7 \%)$, touch $(3 \%)$, smell $(2 \%)$, and taste $(1 \%)$.

Kao (2004) defined color image, as follows: color image is the concept, judgment, preference, and attitude of color, and it emphasizes mental state. In short, color results in affection. Color image denotes color affection, which is more psychological than physical, and can be influenced by cultural background, living environment, race, and customs. From the 
perspective of psychology, Kobayashi (1986) explored the colors, designs, and preferences of consumption, and proposed the findings as reference for related enterprises. In the experiment, hues and color tones were the samples, the researcher investigated 140 colors with different hues and color tones, and treated 23 sets of relative semantic adjectives as the scale to explore color image. This research constructed 3 dimensions of color image spaces, which corresponded to the three color attributes of hues, lightness, and saturation. According to the research findings, brighter color images tend to be influenced by changing hues; while light and dark color images are not affected by hues.

Human feelings toward color or color combinations are considered as color images. Car drivers from Asia, America, and Europe have at least one thing in common: car buyers' preference for car colors is similar. Based on the latest DuPont Automotive Color Popularity Report, among sold cars, silver cars are first among the colors. In 2004, nearly 1 out of every 4 cars were silver, followed by the Top 2 to Top 5 popular colors, white, gray, blue, and black, respectively (Epoch Times, 2005).

Wang et al. (2005) studied car consumers' preference for the color of cars. The ranking of automobile consumers' preferred colors is silver, white, purple, and red, respectively; however, in different areas, the preference for car color is different. In the automotive market of North America, the colors are the richest and the selection is the best. Contrarily, European car owners prefer medium tones, such as silver, black, or gray; while Japan preferred white, and up to $70 \%$ of new cars were white; however, silver was deemed as superior to white, and became the favorite of the Japanese. Noticeably, German taxis are light brown, thus, private German cars are not light brown. Likewise, in New York, people avoid yellow as the color of their cars, as yellow is the color of taxi cars. The above shows the impact of cultural background and living environment (Epoch Times, 2005).

Generally speaking, when purchasing a car, there are many factors regarding color. Using the automotive model as an example, silver is particularly popular in luxury models, red is favored by sports car owners, while those of small cars and special models prefer purple, yellow, and other bright popular colors.

Based on past trends, economy influences people's selection of automobile color. In prosperous times, bright colors are more popular, while during a depression, gray is the mainstream color. Fashion also results in the trend of certain colors, meaning a popular color on a catwalk in Paris might directly influence the automotive color in the future market.

It is not surprising that most drivers select reliable colors, such as silver or white. Regarding the time of use, color might influence the future value of a car. For instance, in the new car market, black cars are always more popular; however, since black cars can easily look old, they are not popular in the market of second-hand cars. Therefore, satisfying and unsatisfying colors can result in different prices when exchanging old cars for new cars. Nevertheless, consumers have different preferences for automobile colors. Generally speaking, bright and popular colors remain popular for ordinary car owners.

While scholars have proposed important strategies for automotive sellers, and conducted differentiation research on quality, promotion, trademark, modeling, channel, and after-sales service, few scholars have explored the issue of color. Color affects people's attention and emotions, indirectly influences their judgment, and is the main factor to stimulate purchase desire. In other words, there is a significant relationship between color preference and 
purchase behavior (Lin, 1993; Tang, 1995). Thus, this study focuses on color image and explores consumers' purchase behavior.

\section{Safety cognition}

"Safety" is defined as safety and security, and means the characteristic or situation of low damage, low danger, low harm, or low damage risk to avoid accident responsibility, protects human life and property from possible damages, and provides a sense of security or avoids fear and worry (You, 2002). Cognition is a kind of psychological function, and refers to people's conscious processing of issues. Burleson and Steiner (1964) indicated that cognition is a kind of complicated process in which people select, combine, consider, memorize, and comprehend sensory stimulus, and interpret them as meaningful and coherent images. Safety cognition, as explored by this study, is to identify the color difference of automotive appearance when the subjects purchased cars, including the possibility of accidents and the key factors of safety.

Cars are very colorful, and while most cars on the roads are black, white, gray, and silver, sometimes we can find bright colors, such as red and yellow. Monash University of Melbourne, Australia investigated 17 automotive colors and the probability of accidents, and demonstrated the correlation between automotive color and accident probability. Professor Sue Furness at the University of Auckland, New Zealand studied more than 1000 cars with different colors, and demonstrated that silver and white are the best choices to prevent accidents. The common results of studies in Australia and New Zealand shows that the accident rates of black, brown, green, and dark blue cars are the highest.

The reason for associating car color and accidents is that colors have the characteristics of distance and expansion. Regarding the distance of color, bright colors are clearer than dark colors, and when driving, they can easily be seen by other drivers. When moving at the same speed, red and yellow cars appear closer than blue and black cars. Regarding the expansion of color, blue and yellow cars look larger than dark black cars, and are more attractive. Silver and white can prevent accidents, as these colors are bright and visible, and researchers further determined that the reflection rates of silver and white are higher than other colors, meaning car identity is significant, and thus, is safer and the accident rate is lower (Hot Topics, 2013).

In addition, according to marketing scholars, when consumers select goods, there is the "Seven-second rule": when facing diverse goods, people can be sure whether or not they are interested in these products in only seven seconds. In this short and critical seven seconds, the importance of the color of goods is $67 \%$, rendering color a key factor for product preference, which demonstrates the safety cognition and importance of automotive color. Since the selection of automotive color is relatively associated to driving safety, this study analyzes consumers' safety cognition of automotive colors in order to suggest that consumers will select safer colors when purchasing cars.

\section{Consumers' car purchasing behavior model}

The framework and meaning of Consumer Behavior includes various fields, such as psychology, sociology, anthropology, economics, and marketing. Williams (1982) defined Consumer Behavior as consumers' different behaviors and activities when purchasing and using products or services. Engel, Blackwell, and Miniard (1993) redefined Consumer Behavior as consumers' activities when acquiring, consuming, and treating products or labor, and includes decision making before and after the actions. Wilkie (1994) defined consumer behavior as consumers' inner, emotional, and physical activities to satisfy their needs and desires in product service, selection, purchase, and treatment. Zaltmam (2000) attempted to determine how humans acquire, consume, and treat products, services, and concepts. Kotler 
(1998) tried to determine how individuals, groups, and organizations select, purchase, use, and treat the goods, service, concept, or experience when satisfying their needs and desires. Based on the previous definitions of experts and scholars of Consumer Behavior, early Consumer Behavior was defined as consumers' purchase to satisfy psychological or daily living economic demands, which now includes systematic modelling and decision making to generalize consumers' selection, purchase, treatment of goods, and services upon the impact of external environment or internal factors. Therefore, the study of Consumer Behavior is an issue for exploration by modern enterprises, and is a key factor for the survival of goods and services.

Tseng (2002) indicated that, when buying cars, modern people tend to consider the color of automotive appearance: dark, light, bright, or gray. Some people prefer white cars that look clean, some prefer red for the concerns of safety and attention, while some select gray cars because it is easier to neglect when dirty. When buying cars, people select color according to their personal principles and decision-making; some consider beauty and others are concerned about safety. Automobiles are mass and standardized products; therefore, consumers can only passively select the colors provided by manufacturers, and they are not always satisfied. Sometimes buyers are unable to fulfill their personal style.

When purchasing a car, all owners can select their preferred color; however, which is more important, safety or beauty and personality? Thus, this study explores consumers' concerns regarding color and consumption behavior when purchasing a car.

\section{RESEARCH METHOD}

\section{Research structure and hypotheses}

According to the research purposes, there are three operational variables: color image, safety cognition, and consumers' car purchasing behavior. This study aims to probe into the impact of color image of automotive appearance, safety cognition, and consumers' car purchasing behavior when Taiwanese car owners purchase cars. According to literature review and past research, this study develops the research framework and hypotheses for study and demonstration, as shown in Figure 1.

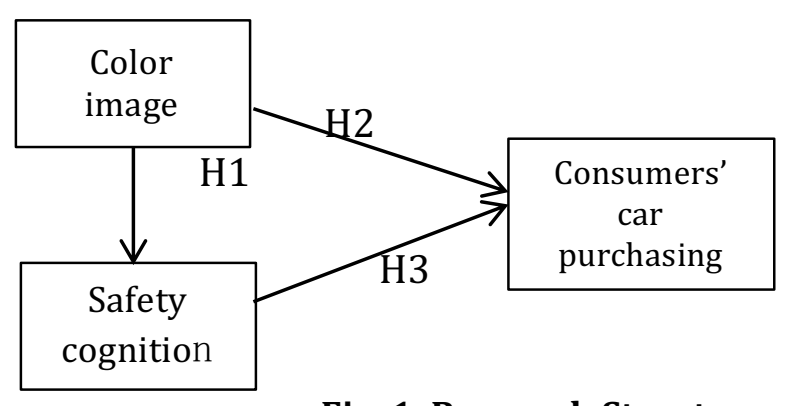

Fig. 1. Research Structure

H1: Car owners' color image positively and significantly influences safety cognition.

H2: Car owners' color image positively and significantly influences consumers' car purchasing behavior.

H3: Car owners' safety cognition positively and significantly influences consumers' car purchasing behavior.

\section{Research tools}

This study adopts a structural questionnaire, and the questions include 4 parts; Part 1 is color image; Part 2 is measurement of safety cognition; Part 3 refers to the measures of consumers' car purchasing behavior; Part 4 is personal basic information. The overall questionnaire 
sources are literature review and modification of questionnaires from past related research. The questionnaire content of three dimensions are shown, as follows.

\section{Color Image}

As the previous questionnaires of scholars failed to show the impact of color image on car selection, this study reorganizes the literature proposed by scholars as the items. Based on the literature of Maya U. Shankar, Carmel A. Levitan, Charles Spence (2010); Chen, Chang, Huang, Chen, and Wang (2010), this study develops 7 items, with scoring based on a Likert 5-point scale.

\section{Safety Cognition}

In past research, few scholars proposed questionnaires related to safety cognition. Thus, the safety cognition questionnaire of this study is based on the limited literature of previous scholars. Questionnaire content is accomplished after reorganization, and after pretesting, exploratory factor analysis, and reliability and validity analysis, improper items are deleted, and items are scored by a Likert 5-point scale.

\section{Consumers' Car Purchasing Behavior}

Based on the Consumer Behavior framework, as mentioned by Liu (2014), this study attempts to introduce an attention-interest-search-action-share (AISAS) model in the Consumer Behavior process to transform passive consumers into active consumers as the reference to explore consumers' car purchase decision-making. The model shows that, consumers recognize the products (attention), they are interested (interest), they search for related information (search), purchase the goods (action), and share their comments (share). The model design is based on items proposed by Wei and Lu (2013). In this study, there are 14 questionnaire items and scoring is based on a Likert 5-point scale.

\section{Research Subjects}

Since legal drivers and buyers of cars are adults, this study treats the population of small private car owners in Taiwan aged above 21, who can drive or purchase cars, and have driving experience, as the samples, and the samples are based on convenience sampling. This study selected the vehicle maintenance plants of 5 different brands, and distributed questionnaires to the owners maintaining the cars waiting in the waiting zone. The survey period is from June 1 to June 30, 2016, there were 150 questionnaires distributed, and 147 were returned; after coding, there were 131 valid questionnaires, for a valid return rate of $87 \%$.

\section{Statistical Analysis Method}

This study conducted analysis by SPSS 21.0 and reorganized, encoded, and analyzed the returned valid questionnaires. According to returned questionnaire results, the researcher first conducted descriptive statistical analysis on the subjects' basic information. Secondly, in order to explore correlation of the variables, by Pearson product-moment correlation analysis, this study probes into the correlation among color image, safety cognition, and consumers' car purchasing behavior. In order to explore the impact and prediction of research variables, the researcher adopts regression analysis to determine the impact of color image and safety cognition on consumers' car purchasing behavior.

\section{Population Statistics and Analysis}

\section{DATA ANALYSIS}

This study conducts a questionnaire survey on car owners in Taiwan, and completes questionnaires according to subjects' actual situations. There are 131 returned valid questionnaires. The basic information of the questionnaire includes gender, age, marital status, 
education level, occupation, monthly income, and residence, as shown in Table 1; and the investigation results of car owners' basic car information is shown in Table 2.

Regarding car owners' gender distribution, there are 70 females (53.4\%) and 61 males (46.6\%); regarding age distribution, most are aged 41-50, including 60 subjects (45.8\%), followed by 31-40 years old, including 33 subjects (25.2\%). Regarding marital status, most are married, including 95 subjects (72.5\%), followed by unmarried, including 36 subjects (27.5\%). Regarding the car owners' educational level, most graduated from graduate schools and universities, including 55 subjects (2\%), followed by colleges, including 53 subjects (40.5\%). Regarding personal monthly incomes, most are NT $\$ 40,001-60,000$, including 37 subjects (28.2\%), followed by NT $\$ 20,001-40,000$, including 27 subjects $(20.6 \%)$, and the least is below NT\$20,000, including 7 subjects (5.3\%). Regarding occupation distribution, the service industry is the most, 41 subjects (31.3\%), followed by military, public service, and teaching personnel, including 29 subjects (22.1\%). Regarding car owners' residential place, most are in Northern Taiwan, including 115 subjects (87.8\%), followed by Central Taiwan, including 10 subjects $(7.6 \%)$.

Table 1. Frequency distribution of demographic variables

\begin{tabular}{|c|c|c|c|c|c|c|c|}
\hline $\begin{array}{l}\text { Demographic } \\
\text { variable }\end{array}$ & Item & Number & Percentage & $\begin{array}{l}\text { Demographic } \\
\text {-variable }\end{array}$ & Item & Number & Percentage \\
\hline \multirow[t]{2}{*}{ Gender } & Male & 61 & 46.6 & Occupation & $\begin{array}{l}\text { Service } \\
\text { industry }\end{array}$ & 41 & 31.3 \\
\hline & Female & 70 & 53.4 & & $\begin{array}{l}\text { Military, civil } \\
\text { servant, and } \\
\text { teacher }\end{array}$ & 29 & 22.1 \\
\hline \multirow[t]{5}{*}{ Age } & $21-30$ & 12 & 9.2 & & Others & 14 & 10.7 \\
\hline & $31-40$ & 33 & 25.2 & & $\begin{array}{l}\text { Manufacturing } 1 \\
\text { industry }\end{array}$ & 10 & 7.6 \\
\hline & $41-50$ & 60 & 45.8 & & $\begin{array}{l}\text { Financial } \\
\text { industry }\end{array}$ & 10 & 7.6 \\
\hline & $51-60$ & 25 & 19.1 & & $\begin{array}{l}\text { Technology } \\
\text { industry }\end{array}$ & 9 & 6.9 \\
\hline & $61-70$ & 1 & 0.8 & & $\begin{array}{l}\text { Freelance } \\
\text { industry }\end{array}$ & 7 & 5.3 \\
\hline \multirow[t]{2}{*}{ Marital status } & Married & 95 & 72.5 & & Student & 4 & 3.1 \\
\hline & Single & 36 & 27.5 & & IT industry & 3 & 2.3 \\
\hline \multirow[t]{5}{*}{ Education level } & $\begin{array}{l}\text { Below junior high } \\
\text { school }\end{array}$ & 0 & 0 & & Homemaker & 3 & 2.3 \\
\hline & $\begin{array}{l}\text { Senior high school } \\
\text { and vocational high } \\
\text { school }\end{array}$ & 4 & 3.1 & & $\begin{array}{l}\text { Mass } \\
\text { communication }\end{array}$ & 1 & 0.8 \\
\hline & Junior college & 19 & 14.5 & & Agriculture & 0 & 0 \\
\hline & University & 53 & 40.5 & Residence & $\begin{array}{l}\text { Northern } \\
\text { Taiwan }\end{array}$ & 115 & 87.8 \\
\hline & $\begin{array}{l}\text { Graduate school or } \\
\text { above }\end{array}$ & 55 & 42 & & Central Taiwan 1 & 10 & 7.6 \\
\hline \multirow[t]{6}{*}{$\begin{array}{l}\text { Per capita monthly } \\
\text { income }\end{array}$} & Below 20,000 & 7 & 5.3 & & $\begin{array}{l}\text { Southern } \\
\text { Taiwan }\end{array}$ & 4 & 3.1 \\
\hline & $20,001-40,000$ & 27 & 20.6 & & \multirow{5}{*}{$\begin{array}{l}\text { Offshore } \\
\text { islands } \\
\text { Eastern Taiwan }\end{array}$} & 2 & 1.5 \\
\hline & $40,001-60,000$ & 37 & 28.2 & & & 0 & 0 \\
\hline & $60,001-80,000$ & 20 & 15.3 & & & & \\
\hline & $80,001-100,000$ & 16 & 12.2 & & & & \\
\hline & Above 100,000 & 24 & 18.3 & & & & \\
\hline
\end{tabular}

The survey results of car owners' basic information of cars are shown in Table 2. In this study, most of the subjects, including 115 people (87.8\%), changed or repurchased cars within five years. Regarding the key factors of car owners' selection of private cars, safety is the most, including 75 subjects (57.3\%), followed by function, including 27 subjects $(20.6 \%)$, and the 
least is car color, including only 1 subject $(0.8 \%)$. Regarding the subjects' favorite car colors: white includes 36 subjects (27.5\%), silver includes 28 subjects (21.4\%), and black includes 23 subjects (17.6\%); the main reason for car owners' preference for automobile color is personal preference, including 59 subjects (45\%), followed by the stability of the color, including 25 subjects (19.1\%), and concern for safety, including 21 subjects $(16 \%)$.

According to the investigation of the color of car owners' current private cars, silver includes 36 subjects $(27.5 \%)$, white includes 29 subjects $(22.1 \%)$, and black includes 24 subjects $(18.3 \%)$. Regarding the reason for the selection of current car color, personal preference is the most, including 67 subjects (51.1\%), followed by the popular color on the market, including 15 subjects $(11.5 \%)$, and concern for safety, including 9 subjects $(6.9 \%)$. Regarding the color appearance of future cars, 32 subjects will select white (24.4\%), 30 will select silver (22.9\%), and 22 will select black (16.8\%). Regarding subjects' current cars, most have medium cars (1600-1999cc), including 45 subjects, (34.7\%), followed by large cars (2000cc), including 31 subjects $(23.7 \%)$. 
Table 2. Survey of car owners' basic car information

\begin{tabular}{|c|c|c|c|c|c|c|c|}
\hline $\begin{array}{l}\text { Demographic } \\
\text { variable }\end{array}$ & Item & Number & Percentage & $\begin{array}{c}\text { Demographic } \\
\text { variable }\end{array}$ & Item & Number & Percentage \\
\hline \multirow{5}{*}{$\begin{array}{l}\text { How often do you } \\
\text { change or } \\
\text { purchase cars? }\end{array}$} & $1-5$ years & 115 & 87.8 & \multirow{11}{*}{$\begin{array}{l}\text { What is the color } \\
\text { of your current } \\
\text { car? }\end{array}$} & Silver & 36 & 27.5 \\
\hline & $6-10$ years & 10 & 7.6 & & White & 29 & 22.1 \\
\hline & $11-15$ years & 4 & 3.1 & & Black & 24 & 18.3 \\
\hline & $16-20$ years & 0 & 0 & & Grey & 20 & 15.3 \\
\hline & More than 20 years & 2 & 1.5 & & $\begin{array}{l}\text { Light blue/ } \\
\text { brilliant blue }\end{array}$ & 5 & 3.8 \\
\hline \multirow{6}{*}{$\begin{array}{l}\text { Regarding the } \\
\text { factors to select } \\
\text { personal private } \\
\text { cars, what is the } \\
\text { most important? }\end{array}$} & Safety & 75 & 57.3 & & Dark blue & 5 & 3.8 \\
\hline & Function & 27 & 20.6 & & Red & 4 & 3.1 \\
\hline & Price & 11 & 8.4 & & Gold/champagne & 3 & 2.3 \\
\hline & Appearance of car & 11 & 8.4 & & Others & 2 & 1.5 \\
\hline & Others & 6 & 4.6 & & $\begin{array}{l}\text { Dark green/ink } \\
\text { green }\end{array}$ & 2 & 1.5 \\
\hline & $\begin{array}{l}\text { Color of automotive } \\
\text { appearance }\end{array}$ & 1 & 0.8 & & Purple & 1 & 0.8 \\
\hline \multirow{11}{*}{$\begin{array}{l}\text { What is your } \\
\text { favorite } \\
\text { automobile } \\
\text { color? }\end{array}$} & White & 36 & 27.5 & \multirow{8}{*}{$\begin{array}{l}\text { What is the } \\
\text { reason that you } \\
\text { choose the color } \\
\text { of your current } \\
\text { car? }\end{array}$} & $\begin{array}{l}\text { Personal } \\
\text { preference }\end{array}$ & 67 & 51.1 \\
\hline & Silver & 28 & 21.4 & & Others & 20 & 15.3 \\
\hline & Black & 23 & 17.6 & & $\begin{array}{l}\text { Popular color in the } \\
\text { market }\end{array}$ & 15 & 11.5 \\
\hline & Red & 13 & 9.9 & & Safety & 9 & 6.9 \\
\hline & Grey & 12 & 9.2 & & Price & 8 & 6.1 \\
\hline & $\begin{array}{l}\text { Light blue/ } \\
\text { brilliant blue }\end{array}$ & 6 & 4.6 & & $\begin{array}{l}\text { Color of cars } \\
\text { displayed }\end{array}$ & 6 & 4.6 \\
\hline & Gold/champagne & 3 & 2.3 & & $\begin{array}{l}\text { Unpopular color in } \\
\text { the market }\end{array}$ & 4 & 3.1 \\
\hline & $\begin{array}{l}\text { Dark green/ink } \\
\text { green }\end{array}$ & 3 & 2.3 & & $\begin{array}{l}\text { Suggestion of } \\
\text { automobile by } \\
\text { salesperson }\end{array}$ & 2 & 1.5 \\
\hline & Other & 3 & 2.3 & \multirow{14}{*}{$\begin{array}{l}\text { In the future, } \\
\text { when you change } \\
\text { the car, what } \\
\text { color will you } \\
\text { choose? }\end{array}$} & White & 32 & 24.4 \\
\hline & Yellow & 2 & 1.5 & & Silver & 30 & 22.9 \\
\hline & Dark blue & 2 & 1.5 & & Black & 22 & 16.8 \\
\hline \multirow{5}{*}{$\begin{array}{l}\text { (Continued) } \\
\text { What is the main } \\
\text { reason that you } \\
\text { prefer this color? }\end{array}$} & $\begin{array}{l}\text { Personal } \\
\text { preference }\end{array}$ & 59 & 45 & & Red & 14 & 10.7 \\
\hline & Stable & 25 & 19.1 & & Grey & 11 & 8.4 \\
\hline & Safe & 21 & 16 & & $\begin{array}{l}\text { Light blue/ } \\
\text { brilliant blue }\end{array}$ & 6 & 4.6 \\
\hline & Fashionable & 13 & 9.9 & & Dark blue & 6 & 4.6 \\
\hline & Other & 13 & 9.9 & & Gold/champagne & 5 & 3.8 \\
\hline \multirow{6}{*}{$\begin{array}{l}\text { What is the } \\
\text { model of your } \\
\text { current car? }\end{array}$} & $\begin{array}{l}\text { Medium } \\
\text { antnmohile }\end{array}$ & 45 & 34.4 & & $\begin{array}{l}\text { Dark green/ink } \\
\text { oreen }\end{array}$ & 2 & 1.5 \\
\hline & Large automobile & 31 & 23.7 & & Yellow & 1 & 0.8 \\
\hline & Small automobile & 27 & 20.6 & & Light green & 1 & 0.8 \\
\hline & Normal SUV & 26 & 19.8 & & Other & 1 & 0.8 \\
\hline & $\begin{array}{l}\text { SUV and multi-use } \\
\text { car }\end{array}$ & 1 & 0.8 & & & & \\
\hline & other & 1 & 0.8 & & & & \\
\hline
\end{tabular}

\section{Descriptive Statistics Analysis}

By means and standard deviations of variables, this study explores car owners' views regarding the items in the scale. By means, the researcher can observe the concentration of variables, and scoring is based on a 5-point scale. When the mean is below 3 , it denotes that car owners do not agree with the item. When the mean is above 3, it denotes that they agree with the item. By standard deviation, this study can understand the difference of car owners' views toward an item. When the standard deviation is low, it denotes that car owners have more 
consistent views. When the standard deviation is high, it denotes that car owners' views are more different. The means and standard deviations of the dimensions are shown in Table 3.

Table 3. Descriptive statistics analysis of variables

\begin{tabular}{|c|c|c|c|}
\hline Color image & Mean & SD & $\begin{array}{c}\text { Mean of } \\
\text { dimensions }\end{array}$ \\
\hline 1. The color of a car influences my selection of a car & 3.51 & 0.77 & \multirow{7}{*}{3.49} \\
\hline 2. The color of a car reminds me of driving safety & 3.62 & 0.64 & \\
\hline 3. The color of a car influences my driving emotion & 3.37 & 0.62 & \\
\hline 4. I prefer cars with a bright-colored appearance & 3.52 & 0.77 & \\
\hline 5. I prefer cars with a dark-colored appearance & 4.11 & 0.73 & \\
\hline $\begin{array}{l}\text { 6. When driving, I often pay attention to other cars with a bright- } \\
\text { colored appearance }\end{array}$ & 3.21 & 0.87 & \\
\hline $\begin{array}{l}\text { 7. When driving, I often pay attention to other cars with a dark- } \\
\text { colored appearance }\end{array}$ & 4.12 & 0.73 & \\
\hline Safety cognition & Mean & SD & $\begin{array}{l}\text { Mean of } \\
\text { dimensions }\end{array}$ \\
\hline 1. I know that the color of a car is associated with accident rate & 3.68 & 0.81 & \multirow{8}{*}{3.60} \\
\hline 2. I know that the color of a car is not associated with accident rate & 2.99 & 0.64 & \\
\hline 3. I know that the color of a car is related to theft rate & 3.59 & 0.78 & \\
\hline $\begin{array}{l}\text { 4. I know that the color of a car shows the visual effect of moving } \\
\text { forward and backward }\end{array}$ & 3.81 & 0.77 & \\
\hline $\begin{array}{l}\text { 5. I know that the color of a car shows the visual effect of expansion } \\
\text { and contraction }\end{array}$ & 3.08 & 0.99 & \\
\hline $\begin{array}{l}\text { 6. I know that the effects of moving forward and backward, and the } \\
\text { expansion and contraction of color, are associated with safety }\end{array}$ & 3.69 & 0.72 & \\
\hline $\begin{array}{l}\text { 7. I know that cars with the appearance of black are those with the } \\
\text { highest accident rate }\end{array}$ & 3.92 & 0.60 & \\
\hline $\begin{array}{l}\text { 8. I know that cars with a silver appearance are those with the lowest } \\
\text { accident rate }\end{array}$ & 4.07 & 0.73 & \\
\hline Consumers' car purchasing behavior & Mean & SD & $\begin{array}{l}\text { Mean of } \\
\text { dimensions }\end{array}$ \\
\hline 1. When purchasing a car, the color of the car attracts me & 2.76 & 0.74 & \multirow{14}{*}{3.46} \\
\hline 2. The color of a car draws my attention & 2.75 & 0.69 & \\
\hline 3. When I see automotive advertising, the color draws my attention & 2.98 & 0.90 & \\
\hline 4. I have a good impression of cars with bright-colored appearance & 3.34 & 0.76 & \\
\hline 5. I have a good impression of cars with dark-colored appearance & 4.01 & 0.71 & \\
\hline $\begin{array}{l}\text { 6. When I have the intention to buy a car, I search for information } \\
\text { related to the color of the automobile on line }\end{array}$ & 3.27 & 0.90 & \\
\hline $\begin{array}{l}\text { 7. When I have the intention to buy a car, I search for the safety } \\
\text { differences of color on line }\end{array}$ & 3.73 & 0.71 & \\
\hline 8. According to the color of the automobile, I compare prices on line & 3.57 & 0.80 & \\
\hline 9. It is worthy to purchase bright-colored cars & 3.63 & 0.90 & \\
\hline 10. It is worthy to purchase dark-colored cars & 4.05 & 0.74 & \\
\hline 11. The automobile color is important for safety & 3.50 & 0.75 & \\
\hline $\begin{array}{l}\text { 12. I share information related to color and safety with my relatives } \\
\text { and friends }\end{array}$ & 3.95 & 0.66 & \\
\hline 13. I share information related to color with my relatives and friends & 3.75 & 0.70 & \\
\hline $\begin{array}{l}\text { 14. I share my car purchasing experience and opinions with my } \\
\text { relatives and friends }\end{array}$ & 3.18 & 0.89 & \\
\hline
\end{tabular}


There are 7 items in the scale of color image. The means and standard deviations of dimension are shown in Table 3; the means of the dimension are 3.21 4.12. Generally speaking, car owners agree that the color image of cars and standard deviations are $0.62 \sim 0.87$, meaning that car owners have different views toward the items. Items $<0.75$ are those with low discrimination for the subjects.

There are 8 items in scale of safety cognition; the means of the dimension are 2.99 4.07. Generally speaking, car owners agree with safety cognition, and standard deviations are $0.60 \sim 0.99$, meaning that car owners have different views toward the items. Items $<0.75$ are those with low discrimination for the subjects.

There are 14 items in scale of consumers' car purchasing behavior. The means of the dimension are 2.75 4.05. Generally speaking, consumers mostly agree with safety cognition, and standard deviations are 0.66 0.90, meaning consumers have different views toward the items. Items $<0.75$ are those with low discrimination for the subjects.

\section{Difference Analysis of Dimensions and Demographic Variables}

In order to determine if there is significant difference between individual basic variables and the dimensions, this study tests the views of different genders and martial statuses toward dimensions by " $t$ test". By "one-way ANOVA", the researcher tests the significant difference between subjects' educational level, age, monthly income, occupation, residential place, car changing or car purchasing frequency, selection factors, preferred colors, reasons of preference, and dimensions.

\section{Independent sample t test}

In order to determine if consumers' characteristics will influence color image, safety cognition, and car purchasing behavior, this study treats consumers' personal basic information as the independent variable and dimensions as the variables for difference analysis. By t testing, this study analyzes the impact of gender and marriage on three dimensions. According to the analysis results of Table 4, Table 5 , and Table 6 , gender shows a difference in color image; and demonstrates that males' color image is superior to females; different genders and marital statuses do not show difference in safety cognition or Consumer Behavior. The results demonstrate that gender and marital status will not influence the subjects' safety cognition or consumers' car purchasing behavior.

Table 4. $t$ test analysis of gender, marriage, and color image

\begin{tabular}{lccccccc}
\hline \multicolumn{2}{c}{ Basic information } & Number & Mean & SD & $\mathrm{t}$ & P value & $\begin{array}{c}\text { Significant } \\
\text { difference }\end{array}$ \\
\hline \multirow{2}{*}{ Gender } & Male & 61 & 2.61 & 0.50 & 2.51 & 0.01 & Yes \\
& Female & 70 & 2.39 & 0.51 & & & No \\
Marital & Married & 95 & 2.52 & 0.54 & & 0.96 & 0.34 \\
status & Single & 36 & 2.42 & 0.45 & & & \\
\hline
\end{tabular}

Correlation is significant at $\mathrm{P}<0.05$ 
Table 5. $t$ test analysis of gender, marriage, and safety cognition

\begin{tabular}{lccccccc}
\hline \multicolumn{2}{c}{ Basic information } & Number & Mean & SD & $t$ & P value & $\begin{array}{c}\text { Significant } \\
\text { difference }\end{array}$ \\
\hline \multirow{2}{*}{ Gender } & Male & 61 & 2.81 & 0.53 & 1.57 & 0.119 & No \\
& Female & 70 & 2.66 & 0.56 & & & No \\
Marital & Married & 95 & 2.72 & 0.54 & & 0.858 & \\
status & Single & 36 & 2.74 & 0.57 & & & \\
\hline
\end{tabular}

Correlation is significant at $\mathbf{P}<0.05$

Table 6. $t$ test analysis of gender, marriage, and consumers' car purchasing behavior

\begin{tabular}{cccccccc}
\hline Basic information & Number & Mean & SD & $t$ & P value & $\begin{array}{c}\text { Significant } \\
\text { difference }\end{array}$ \\
\hline \multirow{2}{*}{ Gender } & Male & 61 & 2.53 & 0.56 & 1.40 & 0.16 & No \\
& Female & 70 & 2.40 & 0.53 & & & No \\
Marital & Married & 95 & 2.52 & 0.55 & & 0.05 & \\
status & Single & 36 & 2.31 & 0.54 & & & \\
\hline
\end{tabular}

Correlation is significant at $\mathbf{P}<0.05$

By one-way ANOVA, this study elaborates other basic information, with the exception of gender and marital status, including subjects' educational level, age, monthly income, occupation, residential place, car changing or purchasing frequency, selection factors, preferred color, and reason for preference as the independent variables, in order to determine if the impact of the basic information is significantly different on the three dimensions. This study also explains the impact, and the result is shown in Table 7. According to the figures in the table, most basic information has no influence on the three dimensions. The few influences are, as follows: color image is influenced by consumers' gender, residential place, selection factors of cars, and color preference. In addition, safety cognition is influenced by consumers' incomes, occupation, and color preference. Finally, consumers' car purchasing behavior is influenced by income, residential place, and selection factors of cars.

Table 7. Consumers' personal basic information and one-way ANOVA of the three dimensions

\begin{tabular}{|c|c|c|c|c|c|c|c|}
\hline \multirow{2}{*}{$\begin{array}{c}\text { Basic } \\
\text { information }\end{array}$} & \multicolumn{2}{|r|}{ Color image } & \multicolumn{2}{|c|}{ Safety cognition } & \multicolumn{3}{|c|}{$\begin{array}{c}\text { Consumers' car purchasing } \\
\text { behavior }\end{array}$} \\
\hline & $\mathrm{F}$ & P value & $\mathrm{F}$ & P value & $\mathrm{F}$ & P value & $\begin{array}{l}\text { Significant } \\
\text { difference }\end{array}$ \\
\hline Education & 2.24 & 0.09 & 0.67 & 0.57 & 0.23 & 0.88 & No \\
\hline Age & 1.04 & 0.39 & 0.39 & 0.81 & 2.19 & 0.07 & No \\
\hline Income & 1.90 & 0.100 & 5.18 & 0.00 & 3.72 & 0.00 & Yes \\
\hline Occupation & 1.17 & 0.32 & 2.02 & 0.04 & 1.50 & 1.50 & No \\
\hline Residence & 2.96 & 0.04 & 2.32 & 0.08 & 4.11 & 0.01 & Yes \\
\hline $\begin{array}{l}\text { Car changing/ } \\
\text { purchasing } \\
\text { frequency }\end{array}$ & 1.13 & 0.35 & 0.94 & 0.44 & 1.02 & 0.40 & No \\
\hline Selection factor & 2.48 & 0.04 & 2.23 & 0.95 & 2.96 & 0.02 & Yes \\
\hline Preferred color & 1.11 & 0.36 & 0.41 & 0.94 & 1.56 & 0.13 & No \\
\hline $\begin{array}{l}\text { Reason for } \\
\text { preference }\end{array}$ & 2.70 & 0.03 & 3.59 & 0.01 & 1.77 & 1.40 & No \\
\hline
\end{tabular}




\section{Correlation analysis of research variables}

By Pearson correlation analysis, this study tests the correlation among color image, safety cognition, and consumers' car purchasing behavior. The simple correlation matrix result is shown in Table 8, which demonstrates that in Pearson correlation coefficient testing, there is positive correlation between color image and safety cognition $(\mathrm{r}=0.513, \mathrm{p}<0.001)$. In other words, the color of a car is associated with car owners' safety cognition, and there is positive correlation between color image and consumers' car purchasing behavior $(r=0.587, p<0.001)$. Correlation testing also shows positive correlation between safety cognition and consumers' car purchasing behavior $(\mathrm{r}=0.606, \mathrm{p}<0.001)$, meaning that consumers' safety cognition is associated with their car purchasing behavior.

Table 8. Correlation analysis of color image, safety cognition, and consumers' car purchasing behavior

\begin{tabular}{cccrr}
\hline & Color image & Safety cognition & $\begin{array}{r}\text { Consumers' car } \\
\text { purchasing behavior }\end{array}$ \\
\hline Color image & Pearson & 1 & $.513^{* *}$ & $.587^{* *}$ \\
& P value & .000 & .000 \\
Safety cognition & Pearson & $.513^{* *}$ & 1 & $.606^{* *}$ \\
& P value & .000 & .000 \\
$\begin{array}{c}\text { Consumers' car } \\
\text { purchasing } \\
\text { behavior }\end{array}$ & Pearson & $.587^{* *}$ & .000 & 1 \\
\hline & P value & .000 & .000 & \\
\hline
\end{tabular}

\section{Regression analysis of color image and safety cognition on consumers' car purchasing behavior}

According to Pearson correlation analysis, there is significant and positive correlation among color image, safety cognition, and consumers' car purchasing behavior. In order to probe into the influence and prediction among the variables, this study adopts regression analysis to explore the impact of color image, safety cognition, and consumers' car purchasing behavior.

According to the regression analysis results of color image on safety cognition, color image has significant explanatory power on safety cognition $(\mathrm{F}=46.18, \mathrm{p}<0.001)$, and $\mathrm{R} 2$ is 0.26 . Thus, color image can explain $26 \%$ of the variance of safety cognition. In other words, color image has explanatory power on safety cognition; color image significantly and positively influences safety cognition.

Color image has significant explanatory power on consumers' car purchasing behavior in regression analysis $(\mathrm{F}=56.83, \mathrm{p}<0.001)$, particularly positive emotion. $\mathrm{R} 2$ is 0.47 , meaning color image can explain $47 \%$ of the variance of consumers' car purchasing behavior. In other words, color image has $47 \%$ explanatory power on consumers' car purchasing behavior; color image significantly and positively influences consumers' car purchasing behavior.

Safety cognition has significant explanatory power on consumers' car purchasing behavior in regression analysis ( $\mathrm{F}=86.37, \mathrm{p}<0.001)$, particularly positive emotion. $\mathrm{R} 2$ is 0.38 , meaning safety cognition can explain 38\% of the variance of consumers' car purchasing behavior. Thus, safety cognition has 38\% explanatory power on consumers' car purchasing behavior; safety cognition significantly and positively influences consumers' car purchasing behavior. According to the analytical results of this study, the findings are shown in Table 9. 
Table 9. Empirical results of hypotheses

\begin{tabular}{|c|c|}
\hline Hypothesis & Testing results \\
\hline $\begin{array}{l}\text { H1: Car owners' color image positively and significantly influences } \\
\text { safety cognition. }\end{array}$ & Supported \\
\hline $\begin{array}{l}\text { H2: Car owners' color image positively and significantly influences } \\
\text { consumers' car purchasing behavior. }\end{array}$ & Supported \\
\hline $\begin{array}{l}\text { H3: Car owners' safety cognition positively and significantly } \\
\text { influences consumers' car purchasing behavior. }\end{array}$ & Supported \\
\hline
\end{tabular}

\section{CONCLUSION}

This study aimed to determine the impact of color image and safety cognition on consumers' car purchasing behavior, and conducted a questionnaire survey on car consumers, with 131 valid returned questionnaires. Statistical analysis of the returns demonstrates the following: Regarding demographic variables, according to the valid questionnaires, the subjects are mostly females aged $41 \sim 50$, and most are married. Regarding educational level, most graduated from graduate schools. Regarding occupation, most are in the service industry, and have NT\$40001-60000 monthly income. Most respondents live in Northern Taiwan. According to car owners' basic car information, the subjects change or repurchase cars within every $1 \sim 5$ years. Most car owners consider safety as the most important factor of car selection, followed by function, price, appearance of car, and color of car. Most car owners' favorite car color is white, followed by silver. Regarding the reasons for color preference, first is personal preference, followed by "stable" and "safe". Regarding the color of respondents' current cars, most have silver cars, followed by white. Investigation results also demonstrated that car owners' current selection is based on personal preference; however, car owners also indicated that, in the future, they mostly intended to choose white, followed by silver and black. Upon previous findings, consumers' selection of car color was based on personal preference, and safety was the most important concern when purchasing a car.

Regarding the difference analysis of this study, genders differ in color image, and males' color perception is superior to females. Marital status, age, occupation, car changing or purchasing frequency, and favorite car colors are not associated with the three dimensions. However, a few influences are, as follows: color image is influenced by consumers' gender, residential place, selection factors of cars, and personal color preference. Thus, this study infers that subjects' gender, residential place, selection factors of cars, and color preference influences car owners' selection of car color. In addition, safety cognition is influenced by consumers' incomes, occupation, and color preference. Therefore, this study reasons that car owners' occupation and monthly average income influences the cognition of safety in the car purchasing behavior. In addition, car owners' favorite car color influences their safety cognition. This study demonstrates that car owners' favorite car color is white, followed by silver. This result matches previous findings, which showed that the accident rate of light colored cars was lowest. Finally, consumers' car purchasing behavior is influenced by income, residential place, and selection factors of cars; therefore, the key factors of economic capacity, residential place, and car owners' selection factor for car safety influences car owners' selection of car color.

This study demonstrates positive correlation between color image and safety cognition. In other words, there is correlation between car color and car owners' safety cognition. Hence, car owners' feeling toward car color reveals significantly positive impact on their safety cognition of the color. Therefore, this study infers that, when car owners select car color, it is associated with the cognition of safety, and there is positive correlation between color image and consumers' car purchasing behavior. The researcher reasons that car owners' actual cognition of color image influences their car purchasing behavior. This study also 
demonstrates that the brightness and darkness of color and safety are the factors of car owners' cognition. The result also shows positive correlation between safety cognition and consumers' car purchasing behavior; therefore, there is correlation between consumers' safety cognition and car purchasing behavior. This study infers that, in car consumption, car owners treat safety cognition as part of the concern regarding car color. Thus, this research indicates that, when purchasing cars, consumers should treat car color as one of the key factors of safety.

The main contribution of this study is that color image and safety cognition significantly influence consumers' car purchasing behavior. This study attempts to explore consumers' feelings toward car color, and its effect. Consumers' safety cognition of car color also influences consumption behavior. However, generally speaking, based on consumers, bright automotive car colors, such as white and silver, are safer. Finally, consumers' color image significantly influences car purchasing behavior. Therefore, in addition to safety cognition, which influences consumers' selection of car color, consumers' personal preference and color image of color preference influence their color selection of automotive appearance when buying cars.

Finally, regarding suggestions for future related research: the development of chromatics is mature, and empirical studies exist in different fields; however, chromatics is mostly applied to the industry of space design. For the automobile industry, the color of automotive appearance is seldom discussed in academic fields as a single subject, thus, there is little related research and literature, which is a limitation of this study. This study encourages future researchers to further develop this research topic. In addition, the color of cars and consumers' car purchasing behavior are significantly associated with personal preference and safety. By quantitative measures, this study takes the previous hypotheses as the test criteria, as it is difficult to explore car owners' psychological variables. This study expects that future related researchers can probe into the psychological issues of consumers' car purchasing behavior.

\section{References}

Burleson, B., \& Steiner, G.A. (1964). Human Behaviours, New York, Harcourt Brace and Jovanovich.

Chan, H.C. (2008). Empirical comparison of image retrieval color similarity methods with human judgment, Display 29, 260-267.

Chen, Y.H., Chang, T.F., Huang, S.W., Chen, P.S., \& Wang, Y.H. (2010). Impact of Color Image on Purchase of Rock and Roll Albums: Taking Consumers in Taipei as Examples, 2010 NTUA Department of Graphic Communication Arts, 48-58.

Engel, J.F., Blackwell, R.D., \& Miniard, P. W. (1993). Consumer Behavior, 7th ed.,Hinsdale, Illinois, Dryden Press, 618.

Epoch Times (2005). Silver is the Favorite for $90 \%$ of Consumers who Select Color of Cars. Retrieved July 16, 2016, from: http://www.epochtimes.com/b5/5/12/9/n1148183.htm

Hot Topics (2013). What is the color which results in the highest accident rate? Scientists' demonstration. Retrieved July 16, 2016, from: http://topnews8.com/1190/

Kobayashi, S. (1986). The strategy of color marketing (2 ${ }^{\text {nd }}$ Edition)(Yang, W.L., trans.). Taipei: Future Career Publishing Corporation.

Kotler, P. (1998). Marketing Management, Analysis, Planning, Implementation and Control, 9th ed, Prentic-Hall Inc.

Lai, C.C. (1997). Color psychology of design, Taipei: Beixing Books.

Li, M.L. (1994). Applied chromatics. Taipei: Yi Fong Tang Publishing.

Lin, S.Y. (1993). Chromatics, Taipei: Sanmin Books.

Liu, W.L. (2014). The management and application of customer relationship, and certification. GOTOP Information Inc. 
Chen, C. T., \& Chen, C. F. (2018). Study on the Impact of Color Image and Safety Cognition on Consumers' Car Purchasing Behavior. Advances in Social Sciences Research Journal, 5(5) 213-228.

Maya U. Shankar, Carmel A. Levitan, Charles Spence. (2010). Grape expectations: The role of cognitive influences in color-flavor interactions, Consciousness and Cognition 19, 380-390.

Tang, Y.C. (1995). Product design and the thinking of color, Industrial Design, 24(2), 58-64.

Travel Encyclopedia (2015). Why color of cars influences accident rate? Retrieved July 16, 2016, from: http://xing.glyx.cn/machine/4214.shtml

Tseng, C.H. (200). Science and culture of color, Taipei County: Yale International Cultur.

Wang, L.T., \& Huang, C.M. (2005). A Study for Females' Feeling on Automobile Colors, Journal of CAGST, $250-256$.

Wei, P.S., \& Lu, HP. (2013). An examination of the celebrity endorsements and online customer reviews influence female consumers' shopping behavior. Computers in Human Behavior, 29(1), 193-201. doi: http://dx.doi.org/10.1016/j.chb.2012.08.005

Wilkie, W.L. (1994). Consumer Behavior;3rd ed.New York,John Wiley \& Sons, Inc.

Williams, T. G. (1982). Consumer Behavior Fundamental and Strategies, St. Paul Minn: West Publishing Co.

You, C.H. (2002). The application of quality management (T.Q.M) on campus crisis management, Educational Research, 10, 167.

Zaltman,G. (2000). Consumer Researchers: Take a Hike, Journal of Consumer Research, 26, 423-428. 